\title{
Sustainable Tourism in Malaysia
}

Policies and Practices

Pradeep Kumar Nair and Toney K. Thomas

\section{(2) OpenEdition}

\section{Journals}

Electronic version

URL: http://journals.openedition.org/tourisme/88

DOI: $10.4000 /$ tourisme.88

ISSN: 2492-7503

\section{Publisher}

Éditions touristiques européennes

\section{Printed version}

Date of publication: 1 December 2013

Number of pages: 60-69

ISSN: 2109-5671

\section{Electronic reference}

Pradeep Kumar Nair and Toney K. Thomas, "Sustainable Tourism in Malaysia », Mondes du Tourisme [Online], 8 | 2013, Online since 01 June 2015, connection on 21 December 2020. URL : http:// journals.openedition.org/tourisme/88; DOI : https://doi.org/10.4000/tourisme.88

\section{c) (i)}

Mondes du tourisme est mis à disposition selon les termes de la licence Creative Commons Attribution - Pas d'Utilisation Commerciale - Pas de Modification 4.0 International. 


\title{
Sustainable Tourism in Malaysia Policies and Practices
}

\author{
PRADEEP KUMAR NAIR_[pradeepn@taylors.edumy] \\ TONEY K. THOMAS [tonythomas@taylors.edumy]
}

Taylor's University, Malaisie

Abstract. The success of tourism has been conventionally measured by tourist arrivals and revenues, but today this is not enough to maintain competitiveness. The current challenges of tourism development in developing countries are the tug-of-war between tourism development plans for economic purposes and sustainable tourism plans. In most of the cases there are reciprocal relationships between "tourism development" and "sustainability". The context is significantly different from country to country when the analysis is focused on economic development goals of tourism. The economic goal of the country, private partnership, and local community involvement together with customer's expectations make tourism a complicated area for sustainable practices. This paper elucidates the performance of "doing tourism" in a sustainable manner complying with the National Sustainable Tourism Policy of Malaysia. It is found Malaysia has a competitive sustainable tourism plan, which has a strong linkage with the goals of public, private and NGOs' goal on socio-economic development. However there is a significant gap in incorporating policies on the macro level of the tourism system.

Résumé. On mesure généralement le succès du tourisme au flux des touristes et aux revenus qui en sont tirés, mais ces critères ne suffisent plus aujourd'hui à garantir sa compétitivité. Dans les pays émergents, les enjeux actuels en matière de développement touristique font l'objet d'une lutte acharnée entre plans de développement du tourisme à des fins économiques et plans pour un tourisme durable. Dans la plupart des cas, il y a réciprocité entre "développement du tourisme" et "durabilité". Le contexte est tout à fait différent d'un pays à l'autre lorsque l'accent est mis sur les objectifs de développement économique du tourisme. L'objectif du pays au plan économique, l'engagement des partenaires privés et des communautés locales, ainsi que les attentes des consommateurs, tout cela peut faire du tourisme un domaine peu propice à la mise en œuvre de pratiques durables. Cet article explicite comment "faire du tourisme" d'une manière durable grâce à la politique nationale pour un tourisme durable en Malaisie. À l'évidence, la Malaisie dispose dans ce domaine d'un plan de développement compétitif, alliant de façon étroite les objectifs publics, privés et ceux des ONG en matière de développement socio-économique. II reste cependant une lacune importante à combler en ce qui concerne l'intégration des politiques dans les éléments externes du système touristique, au niveau macro. 
$\mathbf{T}$ he policy question often raised is: can tourism be economically viable for private companies and local communities, while also being sensitive to environmental, cultural and social needs? The short answer is "yes" (Edgell, Allen, Smith and Swanson, 2008). Mowforth and Munt (2003), Van Egmond (2007) refer to a highly polarized and simplified debate, equating to "tourists $=$ mass tourism = bad" and "travelers = appropriate travelling = good". . Misconceptions are misleading the world's largest industry in terms of sustainable development and management of tourist destinations. The power of tourism is a very large research area and the legitimate utilization of "doing tourism" has a power to change, rejuvenate or literally to define the world's sociocultural and economic system. Sustainable tourism is an interesting topic of discussion and it is crucial to assess where the discussion of sustainable tourism has arrived at.

Most of the studies illustrate the host-guest encounters or an index model, simplifying the sustainable development practices, limiting themselves to give non-practicing measures a wide publicity with existing scenario of environmental issues. But relating tourism to holistic sustainable practices is rarely seen and there is an extreme research gap in the practice of sustainability in tourism and its allied sectors. Many authors argue that tourism should be the subject of interdisciplinary, multidisciplinary (Wang, 2000;
Mowforth and Munt, 2003; Van Egmond, 2007). But the practice of tourism as an extradisciplinary (Tribe, 1997) is less discussed in the successful tourism management. The United Nations World Tourism Organization (UNWTO) strongly advocates tourism as tool for alleviation of poverty in poor countries. All over Latin America, Africa and parts of Asia numerous tourism projects are initiated by local authorities, communities or non-governmental organizations (NGOs) to contribute to local and regional economic development. Many projects, however, fail to reach economic goals. They either have problems in attracting the required volume of visitors, so as to pass the break-even point, or host the "wrong" (i.e. non lucrative and/or harmful) visitors. Most projects are inward-oriented rather than market-oriented. Here the issues associated with tourism development are that sustainable development is a global holistic approach for any tourist destination in the world. Many destinations lack knowledge of potential markets. Understanding the "tourist" phenomena as well as the ability to employ specific marketing tools, are crucial success factors for tourism development and for defining a more sustainable tourism.

Managing sustainable tourism depends on forward-looking policies and sound management philosophies that include a harmonious relationship among local communities, the private sector and governments regarding developmental practices to protect that natural, built and cultural environment while being compatible with economic growth (Edgell, Allen, Smith and Swanson, 2008). Practicing sustainable tourism in developing countries is even more crucial, as shows Malaysia as an example of South East Asia countries now opened to the Asian market. Tourist flows to the regional countries are widely heterogeneous. Thus, the potential tourism markets of the South East Asian countries are heterogeneous in nature. Managing tourism to the heterogeneous tourists is extremely complex and practicing sustainable tourism is further a complex process. The problem here is that the sustainable tourism products can be successfully sold to tourists who are not specifically seeking it. Thus, sustainable development is not to be used in the tourist destination but it is a process that should be used on the "tourism system" as a whole.

\section{OBJeCtives}

\section{AND METHODOLOGY}

The objectives of this study are : - to analyze the tourism policy in terms of the existing need to implement the development sectors of tourism;

- to benchmark the major sustainable tourism practicing plans with major international sustainable tourism policy guidelines;

- to identify the gaps of the existing sustainable tourism policy initiatives with the current scenario of tourism development in Malaysia. 
The qualitative approach of this study mainly deals with analysis of the National Tourism Policy in Malaysia, includes also the evaluation of the Ninth Ecotourism Plan of Malaysia. Generic benchmarking of the strength and weakness of this plan has also been discussed in comparison with local Agenda 21 guidelines of sustainable tourism development in Malaysia, and with international sustainable tourism plans and policies, such as UNWTO, Global Observatory on Sustainable Tourism (GOST), United Nations Environnement Progamme (UNEP), and Pacific Asia Travel Association (PATA). A comparative analysis of other national, local and NGOs plans for sustainable development has also been done to arrive at a specific conclusion on the effectiveness of the Malaysian Sustainable Tourism Policy.

\section{TOURISM IN MALAYSIA}

Tourism in Malaysia is comparatively young. As a result, Malaysia remains a relatively unknown destination, and after 1980's tourism development, Malaysia recognizes that tourism can play a vital role in social and economic development, as well as in fostering national integration and unity. Prior to the campaign "Visit Malaysia Year 1990", Malaysia was frequently marketed as only an element of a wider "tourist circuit", including the neighboring countries of Thailand, Singapore and Indonesia (King, 1993; Hamzah, 2004). Malaysia's tourism resources are unique in characteristics, and historical development of tourism in the country indicates it has attracted by wildlife, scenery, forests and beaches. The well-known sites are mainly full of multiple attractions. Malaysia has diversified tourism resources, ranging from beaches, cities, culture, heritage, jungles, food, resorts, health, business and shopping. The location of Malaysia is another strategic advantage of the future development of tourism. Located at the centre part of South East Asia, Malaysia has the following strategic advantages:

- Malaysia is price effective. In developing countries the middle class people's ambition is to have a foreign trip as tourists, and Malaysia offers the best value of money for the middle class tourists.

- As a multicultural country, Malaysia has sentimental visits: VFR (Visiting Friends and Relatives) from the countries such as China and India.

- Malaysia climate is de facto equatorial, which allows for traveling throughout the year.

- Malaysia's variety of attractions and tourism resources can cater all categories of tourists.

- Geographical proximity to the new coming budget markets paves the way for tourism boom in Malaysia. The role of budget carriers to the exploring of markets boosts the tourists' arrivals from countries in Asian continent.

Analyzing the above facts, Malaysia's tourism market is very much diverse and heterogeneous; this characteristic itself is a major threat for the sustainable development and management of tourist destination in Malaysia. Sustainable development has always been measured in terms of the three indicators of sustainable tourism, social, economic and environmental dimensions. Narrowing down these dimensions we will see that many other factors are influencing the sustainable development of tourist destinations.

The " 12 sustainability aims" and the policy instruments described in the UNWTO/UNEP guide: Making Tourism More Sustainable. A Guide for Policy Makers have become international references for initiatives at different levels. These aims are:

1. Economic visibility

2. Local prosperity

3. Employment quality

4. Social equity

5. Visitor fulfillment

6. Local control

7. Community well-being

8. Cultural richness

9. Physical integrity

10. Biological diversity

11. Resource efficiency

12. Environmental purity

As a comparison, Global Sustainable Tourism Criteria (GSTC) focus mainly on demonstrating that effective sustainable management maximize social and economic benefits to the local community and minimize negative impacts, maximize benefits to cultural heritage and minimize negative impacts as well as maximize benefits to the environment and minimize negative 
impacts. The practicing areas of sustainable tourism are more or less similar from the United Nations Development Programme (UNDP) or UNEP criteria. As regards the environmental protection and tourism development, Malaysia has adopted the PATA code for environmentally responsible tourism within a legal and institutional framework.

Above indicators are not only managed in the tourist destination only, their performance is further influenced by the nature of visit and the type of tourists. Therefore, the effectiveness of sustainability must be operated in micro and macro levels. As shown in the representation of the tourism system ( $c f$. figure $1)$, traveler-generating regions play an important role in defining the best practice. Most of the sustainable destination management policies limit the policy in the destination level. This can be one of the major reasons for dropping the expected level of benefits on practicing sustainable tourism in many tourist destinations.

Figure 1 shows the macro and micro level approach of sustainable development of tourist destinations. Destinations micro level planning will internally strengthen the stability of destination development and management. Most of the destinations have an internal policy and planning on sustainable tourism development. Many times the efficiency drops due to the lack of control of the development authority to the macro level tourism sys-

\section{Figure | - Structuring sustainable tourism policy in the tourism system}

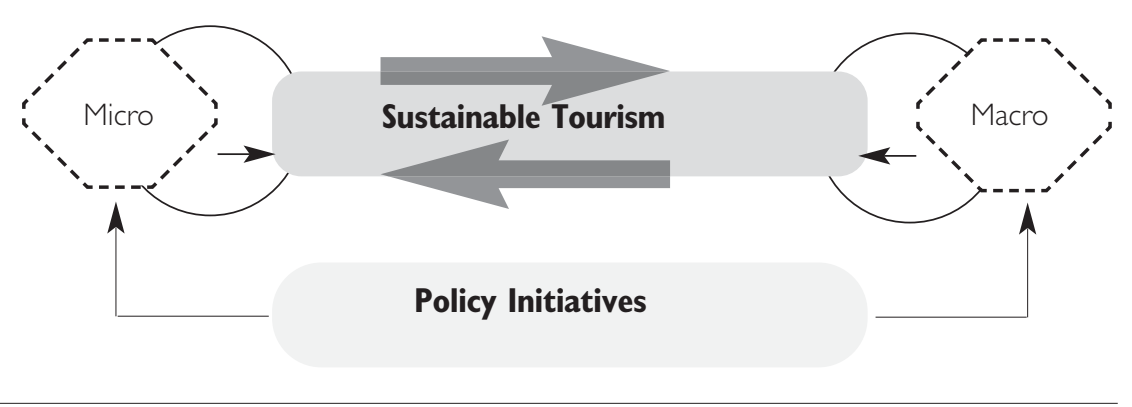

Figure 2 - Tourism, a shared service industry

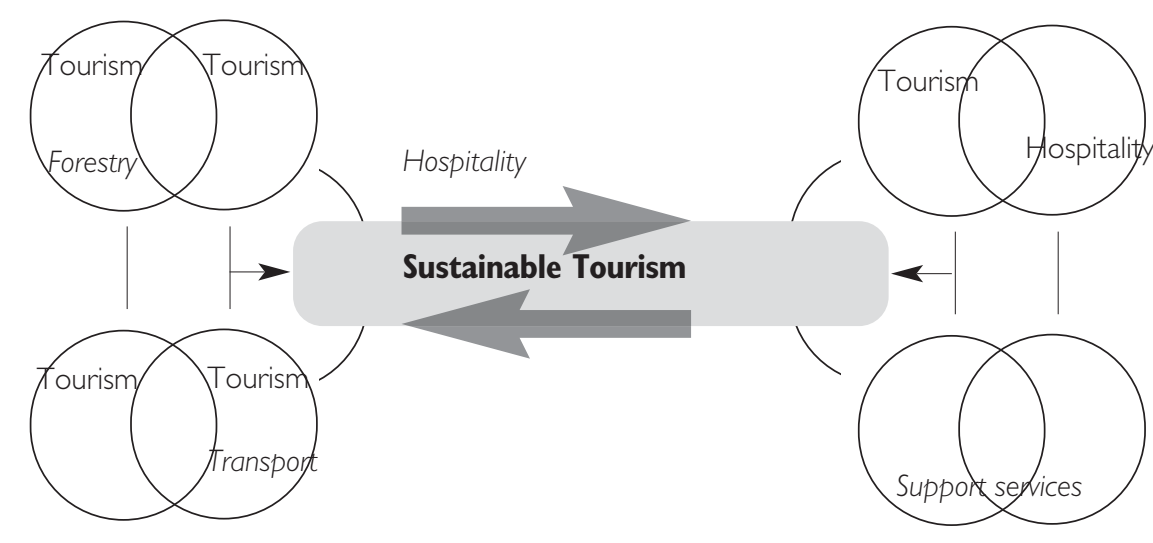

tem, which is further affecting effective implementation. A policy framework only within the micro level at the tourist destination is halfhearted and isolated. It offers less effectiveness in the overall practice of sustainability in the entire tourism system.

The ownership within tourism many times falls under different competences. For example a national park has high value in the potential tourism market and the utilizing of the park's resource could trigger economic development. But in many countries national parks and biosphere reserves are directly under the control of wildlife authorities or forest department. Their ultimate aim is not a monetary benefit, but the conservation and preservation effort. The ownership of resources is therefore a potential source of conflict within the total sustainable management of the tourist destination. Many times there will be conflicts of interest in policy implementation or one policy does not comply with the policy of the other. 
On the macro level of the tourists, it is a different problem. The visitor's attitude and perception varies highly from one market to another. Like other products, tourism also becomes more consumer centered, consumers focus less on the sustainability aspects because their visit is temporary and highly influenced by the factors such as modernity, rationalization, alienation, romanticism, etc. Destination policy and planning may not be the only solution for destinations sustainability. This issue is illustrated in figure 2.

The foremost issue in implementing the sustainable practices in tourist destination/attraction is the ownership and power. Tourist attractions imply governance problems, and in several areas, tourism authority has less control. Most of the time the destination planning and development is overshadowed by objectives of the actual controlling authorities. From the figure 2 it is clearly understandable that tourism itself is a shared service with other resources and infrastructure for countries general development.

\section{Malaysian Tourism Policy INITIATIVE AND SUSTAINABLE TOURISM DEVELOPMENT}

Malaysia is one of the twelve mega-diverse countries in the world that accepts the importance of preserving its social, environmental and cultural wealth heritage (Organization for Economic Cooperation and Development, 2003). Malaysia's sustainable tourism policy and legislation is in line with the Agenda 21. There is evidence that indicate that Agenda 21 have been adopted in the national master plan. To speed up the development of tourism industry, the Malaysian Tourism Policy was formulated in 1992. The policy had identified ecotourism as one form of tourism to be expanded and sustained. It was followed by a more specific national ecotourism plan three years later. The National Ecotourism Master Plan was drafted in 1995 and was accepted by the government in 1996. This plan was intended to provide a general framework to assist the government in developing the country's ecotourism potential. Under the plan, the definition of "ecotourism" follows that of the International Union for the Conservation of Nature (IUCN). Ecotourism is defined as "responsible travel and visitation to relatively undisturbed natural areas in order to enjoy and appreciate nature that conserves the environment and sustains the well-being of local people”. As a result, quite a number of the tourism destinations in Malaysia have been gazetted as terrestrial or marine protected areas in various categories such as forest reserves, wildlife reserves, sanctuaries, wetlands and marine parks. In order to ensure the success of the ecotourism plans, joint efforts between the various levels of government, the private sector and the local communities were planned and carried out to maximize the economic, sociocultural and envi- ronmental benefits it has to bring. Although the Ministry of Culture, Arts and Tourism (MOCAT) acts as a single coordinating body to spearhead the overall implementation of the National Ecotourism Plan, the Ministry recognizes the imperative role of the private sector and specifies roles for all sectors of federal, state and local authority, private business, NGOs and other players. Under the Ninth Malaysia Plan a more integrated approach to tourism planning and management is to be undertaken (Economic Planning Unit, 2006) through preserving as well as enhancing the existing and natural and cultural assets. In addition, the role of the State Tourism Action Councils (STAC) will be further expanded to include regular monitoring and evaluating of project outcomes. At the local level, local authorities and communities are encouraged to have a more active role from the beginning of the projects so as to minimize environmental destruction. For businesses, such as hotels and resorts, they "will need to incorporate, among others, water and energy conservation as well as waste disposal aspects in the implementation, management and maintenance plans" (EPU, 2006). More emphasis will be put on the preservation of the natural attractions to enhance ecotourism as well as preservation of the heritage tourism such as historical sites, buildings and artifacts that are categorized under preservation of the natural attractions. For instance, Taiping is promoted 
as the heritage city of Perak and is listed as one of the ten tourism attractions. As argued by SitiNabiha, Abdul Wahid, Amran, Che Haat \& Abustan (2008), the declaration of Taiping as a heritage town by the STAC is "insignificant unless the state or municipal is serious at promoting it as such. The status given via 'heritage' should be respected and acted upon fittingly." In addition, more value added activities are incorporated in the agrotourism and homestay programs (EPU, 2006).

\section{MinI CASE I:}

\section{Sustainable Cameron Highlands}

The Cameron Highlands will always have environmental issues as long as there are "tidak apa" people in the government approving projects without a care, perhaps due to the lack of transparency in the process of approving projects. The Cameron Highlands is not be the only affected place, there are many examples of gross neglect in preserving the environment in every part of Malaysia. "The Kampung Tersusun (Melayu) Anggerik project in Cameron Highlands should be cancelled to prevent tragedies related to hill development. There should not be any form of physical development in this environmentally sensitive area. "Hillside hazard" which said phase one of Kampung Tersusun (Melayu) project had encroached into "forbidden" zones. The proposed settlement scheme fell on a billy terrain within Mentigi Forest Reserve and Gunung Jasar.
In view of the grave danger and previous tragedies in highland areas, it was vital the proposed development be relocated to a safer location" (The Star, 20 I0). The issues of deforestation and erosion or landslide were considered serious. These problems not only bring negative effects but also threaten the tourism sector in Cameron Highlands. In tourist perception, conservation measures are needed to protect the environment in Cameron Highlands (Boon, 2007).

Looking on the above case, the development of tourism in Cameron Highlands is a threat to the ecosystem. The development is either not ideally planned or unable to practice the sustainable development along with tourism. The consequence is the gradual setback of tourism. Practice of sustainable tourism should not be after an issue, it must be an upbeat initiation before an issue. Most of the tourist destinations activate sustainable tourism initiatives "after" an issue.

\section{An analysis of local Agenda 2I implications in Malaysia}

Air transport and hotels sectors have control over the major initiatives like environmental purity, resource efficiency, cultural richness and social equity. As part of the humble initiative of Green Globe Benchmarking, Kuala Lumpur International Airport (KLIA) has awarded the Green Globe certified status a prestigious accolade that recognizes KLIA's operation policy and best practices in sustainable tra- vel and tourism in the consecutive years from 2004 onwards. Valuing the importance of protecting and preserving the environment surrounding KLIA, Malaysia Airports is committed to operate KLIA within and above the confines of the environmental social sustainability policy that conforms to the final and highest level of the Green Globe certification program. This policy was designed by Malaysia Airports to achieve compatibility between the economic considerations, the conservation of the environment and the protection of the social and cultural heritage of Malaysia that can be influenced by current and future activities of KLIA. As such the airport is attuned to: (i) an architectural concept of a symbiosis of building and nature; (ii) eco-airport features that seek to preserve and foster the local ecosystem; and (iii) the commitment to co-exist harmoniously with the surrounding community. Apart from the travel sectors there are nine hotel and resorts that successfully achieved the Green Globe certification upon their successful practice of sustainable management of properties in Malaysia. They are: Crowne Plaza Mutiara, Kuala Lumpur; Holiday Inn Glenmarie, Kuala Lumpur; Holiday Inn Melaka; Holiday Inn Resort, Penang; Kuala Lumpur Convention Centre; Kuala Lumpur International Airport Hotels; Melia Kuala Lumpur; Club Med Malaysia; eastern shore of Malaysia. These service providers in tourism have shown excellent operations in line with the 
Agenda 21 Green Globe practices. Club Med's efforts to preserve the environment extend to energy and water consumption. Energy is recovered to fuel boilers for hot water channeled to guests' rooms.

\section{MINI CASE 2: \\ Practicing sustainable tourism: Club Med through GREEN SHADES}

Club Med Cherating Beach has been committed to preserving the environmental, sociocultural wellbeing of its setting. The resort also has an efficient watering system that uses water from a man-made lagoon for watering plants. The lagoon is part of the resort's natural wastewater treatment system. The resort has started nature conservation awareness for young guests. This is a new nature-based concept, with a focus on nature education and the use of sustainable local materials for the refurbished clubhouse, use of passive solar design for natural light, natural filtration fishponds and energy-saving lighting. Club Med also supports the Fisheries Department, with part of the resort's proceeds going towards the department's turtle sanctuary activities. Apart from committing to the Green Globe program, the resort also supports the local community through its Corporate Social Responsibility programs. The resort employs more than 100 locals in the area, and organizes scheduled local cultural shows at the resort as well as bringing guests to visit several places of interest nearby.

\section{Mini CASE 3:}

\section{Practicing COMmUNity toURISM INITIATIVES}

Bario: Pro-poor communitybased approach. Practicing sustainable tourism is now widely spread to tourist attractions, especially the authentic nature and culture of communities benefit from tourism development. The study of communitybased tourism concluded that few projects have generated sufficient benefits either to provide incentives for conservation -the objective of ecotourism- or to contribute to local poverty reduction (Goodwin, 2006; Harris, 2009). Bario is an example of an isolated collection of settlements nestled in the Kelabit Highlands in the north of Sarawak. Tourism in Bario has grown from its accidental beginnings to being a mainstay of the local economy, embracing along the way many different forms, including ecotourism, adventure tourism, cultural tourism, research tourism, and its latest manifestation, development conferencing. The growth of tourism in Bario is closely interwoven with other aspects of the social and cultural development of the community, which it has grown alongside, and the story of the industry provides an insight into the possibilities for other communities wishing to take advantage of their natural assets towards locally driven development. Tourism in Bario depicts how a pro-poor communitybased approach to tourism can integrate with local development in a mutually reinforcing process that has delivered more than income- generating opportunities, but which also fosters a wider reinvigoration of the local economic and social life of the community (Harris, 2009). This has a wider multiplier effect of sustainable practices and enrichment of sociocultural aspects together with economic development.

Homestay and community-based tourism initiative of Sabah tourism: a success story. Homestay in Sabah is another valuable project with a wider multiplier socio-economic effect of tourism in eastern Malaysia. This initiative is a well-focused project with a great symbiosis with tourism development and sustainability. The strategically located homestays: Penangpang, Papar, Kota Belud, Kudat, Tambunan, Keningau, Kundasang, Tamparuli and Sandakan, have developed with specific tourism development objectives such as: (i) at tourist level, a unique opportunity to experience the authentic culture of Sabah, to experience astonishing things like ethnic food, real linkage of local people and their culture without a distance (visitors are not guests but part of home); and (ii) at community level, direct spending of money has higher level of direct, indirect and induced economic impact, opportunity for community conservation initiatives, and finally it is a responsible travel initiative.

The promotion of Malaysia with the aspect of gastronomic tourism by the Ministry of Tourism is another successful step towards the social equity of tourism development in Malaysia. In the context 
of resource efficiency and environmental purity, Taman Negara National Park is a good example. Taman Negara National Park covers more than 400,000 hectares of tropical rain forest and about five times the size of the state of Perlis; it was gazetted in 1939 for the conservation of indigenous fauna and flora and as well as for the promotion of sustainable tourism. Conservation of the biodiversity resources within the park is given priority through a zoning system prescribed by the management plan. Wilderness conservation constitutes more than $90 \%$ of the park area while the rest is zoned for recreation, research, education and high utilization. The high utilization zone, which is only about $0.2 \%$ of the park, is dedicated to entry points of the park where the development of tourism related infrastructure is permitted (The Star, 2010).

\section{A CRITICAL REVIEW OF} THE NATIONAL ECOTOURISM POLICY WITH A GENERIC

\section{BENCHMARKING OF PRACTICES}

Malaysia's current concept and devised strategies are internationally defined sustainable tourism management plan; it has a broader definition on what is to be done for achieving sustainable tourism. All forms of tourism recommended under the National Ecotourism Plan aim to be sustainable tourism, but the concept of sustainable tourism is much wider than just ecotourism;

Figure $3 \cdot$ National sustainable tourism policy in a nutshell

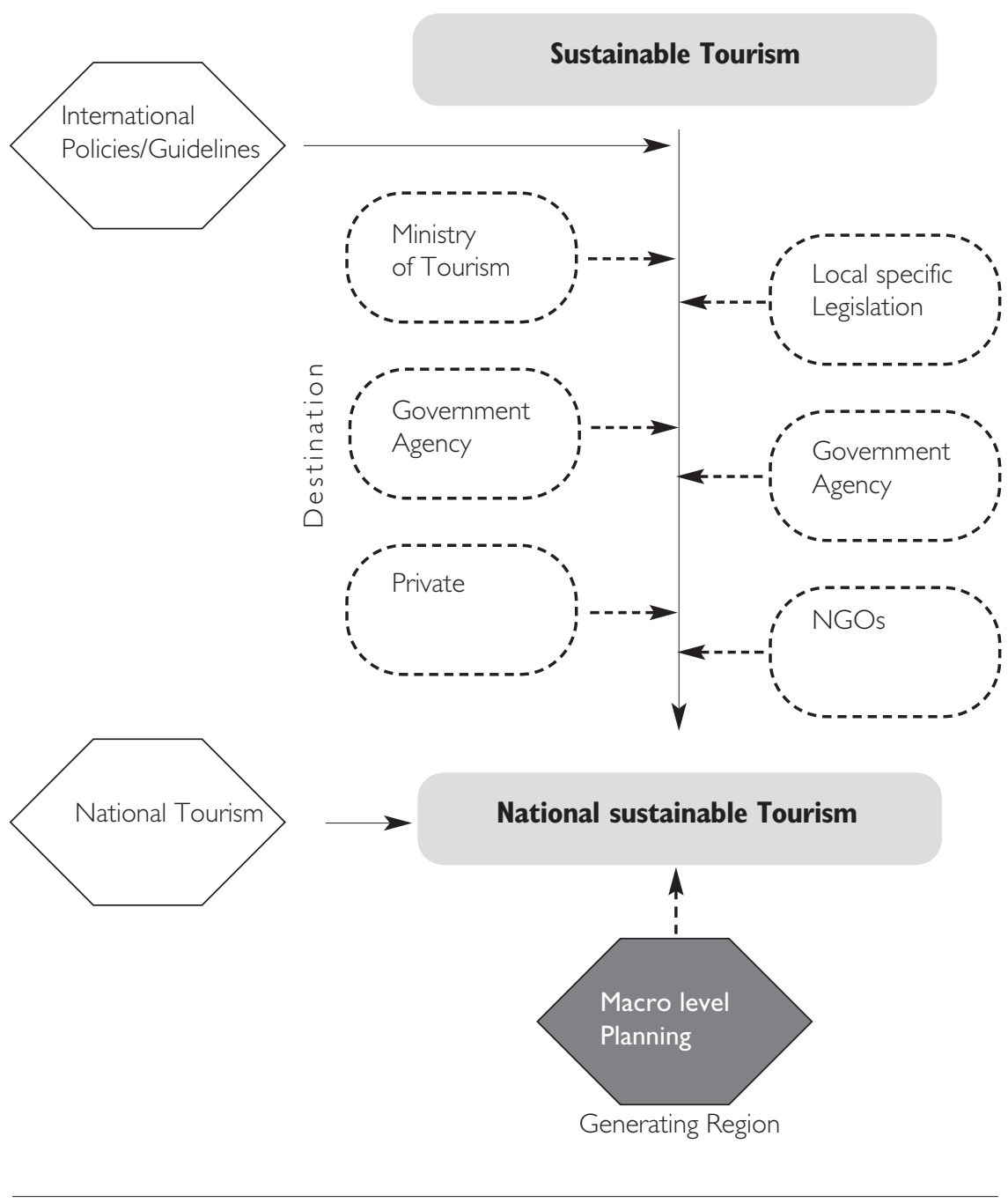

all forms of tourism should aim to be sustainable. This concept is then related to responsible tourism so as to provide a more holistic approach to the development of ecotourism, as well as instilling a sense of responsibility. In Malaysia the development of ecotourism is the function of many government agencies including Malaysia Tourism Centre (MaTIC), the Department of Wildlife and National Parks, Forestry, and
Fishery departments, with collaboration of private sector developers and NGOs. The national sustainable tourism framework is illustrated in figure 3 .

From figure 3 it is revealed that the national sustainable tourism policy is framed with expert consultation of international, national and local governing authorities and that there is a horizontal linkage plan involved to protect the interest of 
other major departments/agencies of Malaysia. Malaysia's sustainable tourism policy has well incorporated within the UNWTO/UNEP guide: Making Tourism More Sustainable. A Guide for Policy Makers and the Agenda 21 local plan specifically considering Malaysia as one of the 12 mega-diverse countries in the world that accepts the importance of preserving its social, environmental and cultural wealth heritage. The role of the Malaysian government in promoting sustainable tourism is evident in the existing legal and institutional framework. Agenda 21 clearly binds local authorities and communities to take lead in the implementation of the sustainable development at a local level. As a local initiative, Khoo (200I) noted that Sustainable Penang Initiative (SPI) was launched with the purpose of ensuring a more balance and holistic development in Penang with consultative partnership with the government, the business community and civil society (Siti-Nabiha et al., 2008).

Tourism in Malaysia also provides a platform for realizing socio-economic and distributive benefit policies. This programme involves the participation of the rural community in providing experiential learning activities such as rubber tapping, traditional songs, dance and crafts as well as serving local dishes. Community-based tourism principles are applied in the implementation of homestay and ecotourism programs. Currently, there are 140 homestay programs, participated by
3,287 operators. The Indigenous Community Tourism Packages were formed based on the ecotourism concept. In the first six months of the year, 3,446 packages were sold, generating revenue of RM165,000. This mainly benefited the orang asli community (Hong Peng, 2009). Apart from the sociocultural benefits from tourism, Malaysia has approved budget of the Ninth Malaysia Plan (2006-2010) with an approved budget of RM260.6 million for 73 projects.

Malaysia's outlook is very good: the country has vast potential as regards the ecotourism industry in the Asia Pacific region. To further enhance the growth of ecotourism industry there should be further collaborations between the private sectors and the public sectors in the countries concerned (Abdullah, 2006). Therefore, sustainable tourism policy in Malaysia can be weighed as one of the strong implementation plan that meets the needs of national development plan of Malaysia. But the major constraint on the practice of sustainable tourism in Malaysia is due to the macro level gap.

The major share of successful sustainable tourism practices lies in the macro level, i.e. the input from travelers in the tourism generating country in the tourism system. The tourist, as central actor of the tourism system, has direct influence in "doing sustainable tourism". The majority of the policies however target the tourist destination region (micro level), where sustainability has to be practiced by the tourists from the tourist-generating region. The definition of the practices regulates therefore the distribution channel. The question is to raise the tourists' awareness of sustainability. Tourism in a mega-diverse country can therefore create the brand image as a successful sustainable tourist destination, which can further strengthen the overall destination image. Yet, since tourism in Malaysia is relatively new, tremendous increase of tourist arrival may make it difficult to practice sustainable tourism.

Malaysia's tourism resources are sensitive, the abundance of natural wealth can be utilized as a prime tourism spot. However, managing natural sites is more complicated as it has direct adverse impact to the ecosystem and integrity of attractions. Malaysia's current tourism market is more diverse and heterogeneous, stemming from the variety of tourists. Therefore, it is difficult to control and manage the visitor's practices for supporting sustainable tourism in Malaysia.

\section{CONCLUSION}

Malaysia's sustainable tourism plan is to comply with many international sustainable tourism policies; it has covered the major aspect of practicing sustainable tourism. It would be a better plan in reality, if the sustainable tourism strategy could be integrated with other management functions and actions whose strategy should be implemented. Tourism has many other micro sectors, for examples local transport and car rentals. In a survey 
by The Expat, a Kuala Lumpurbased magazine, taxis are rated "the worst [for] quality, courtesy, availability and ride experiences" in a sampling of 200 foreigners from 30 countries. "The drivers are road bullies and extortionists, a national shame and pose a serious threat to the country's tourism industry", the survey found. (Y. Sulaiman, 2008). From the above survey it is clear that the implementation part of sustainable tourism has still to be achieved. There are gaps, and micro sectors sustainable tourism planning must be given as equal importance as the major destinations sustainability practices. There are excellent opportunities in extending the maximum benefits to the major areas of sustainability in Malaysia. However the practices of these opportunities must be unified to all sectors of tourism.

\section{BIBLIOGRAPHY}

Junaida Lee ABDULlAH, "Ecotourism Opportunities in the Asia Pacific Region: Malaysia", Proceedings $4^{\text {th }}$ Asia Pacific Ecotourism Conference, Jakarta, Indonesia, 2006.

Boon Hiong Lee, Pembangunan Ekopelancongan di Cameron Highlands: Satu Kajian Kes, Universiti Sains Malaysia, 2007.

Economic Planning Unit (EPU), Economic Instruments for Environmental Management in Malaysia, Prime Minister's Department, Malaysia, 2006.

\section{David L. Edgell, Maria DelMastro Allen,}

Ginger SMITH \& Jason R. SWANSON, Tourism Policy and Planning: Yesterday, Today and Tomorrow,

Elsevier, 2008.

Harold GoodWIN, "Community-based tourism:

Failing to Deliver", ID2I Insights, n 62, 2006.

Roger W. HARRIs, "Tourism in Bario, Sarawak, Malaysia: A case study of pro-poor communitybased tourism integrated into community development", Asia Pacific Journal of Tourism Research, vol. 14, n², 2009.

Ong Hong PeNG, "Initiatives to think and act tourism", 2009

[http://www.thestar.com.my/story.aspx/?file=\%2f200 9\%2fl I\%2f7\%2fnation\%2f4832869\&sec=nation].
}

KHOO Salma Nasution, The Sustainable Penang Initiative: Creating State-Society Partnership for Sustainable Development, International Institute for Environment and Development, 2001.

Victor T. KING, "Tourism and Culture in Malaysia”, in Michael HITCHCOCK, Victor T. KING \& Mike PARNwELL (eds.), Tourism in Southeast Asia, Routledge, 1993.

Martin MOWFORTH \& lan MUNT, Tourism and Sustainability: Development and New Tourism on the Third World, Routledge, 2003.

OECD, "OECD Environmental Indicators, Development, Measurement and Use", Reference Paper, 2003.

Abdul Khalid Siti-Nabiha, Nasbiah AbDUl WaHID, A. Amran,

H. CHe HAAT \& Ismail ABUSTAN, "Towards a Sustainable Tourism Management in Malaysia", Lesij, vol. XV, n² 2, 2008.

The Star, "Stop Project in Cameron", 2010

[http://wnw.thestar.com.my/story.aspx/?file=\%2F20 I0\%2FI\%2FI 2\%2Fnation\%2F5 454309\&sec=nation].

Yusof SULAMAIN, "Malaysian cab drivers: Malaysian tourism problems hounds PATA travel delegates in Hyderbad", eTurboNews, 2008

[http://www.eturbonews.com/5273/malaysia-tourism-problems-hound-pata-traveldelegate-hyderabad].

John TRIBE, "The indiscipline of tourism", Annals of Tourism Research, vol. 24, n 3, 1997.

Ton VAN EGMOND, Understanding Westem Tourists in Developing countries, Cabi Publishing, 2007.

Ning WANG, Tourism \& Modernity. A Sociological Analysis, Pergamon Press, 2000. 